\title{
Evaluation of a Feed Plant Additive for Coocidiosis Control in Broilers Herbals for Coccidiosis Control
}

http://dx.doi.org/10.1590/1806-9061-2018-0846

\begin{abstract}
Euthor(s)
Sánchez-Hernández $\mathrm{C}^{\prime}$

(iD) https://orcid.org/0000-0002-8574-7829 Castañeda-Gómez del Campo JA

(iD) https://orcid.org/0000-0003-2571-5355 Trejo-Castro L'

iD https://orcid.org/0000-0002-0127-6733 Mendoza-Martínez GDIII

Gloria-Trujillo A ${ }^{\text {III }}$

iD https://orcid.org/0000-0002-8613-6464

(iD https://orcid.org/0000-0003-3204-5476

Nuproxa México $S$ de RL de $C V$, Sendero del Mirador \#36, Milenio III- A, 76060, Querétaro, México.

Servicios de Consultoria y Asesoria en Parasitologia Animal. 62550. Jiutepec, Morelos, México.

III Doctorado en Ciencias Agropecuarias, Division de Ciencias Biologicas y de la Salud, Universidad Autónoma Metropolitana - Xochimilco. Calzada del Hueso 1100, 04960. Villa Quietud, Coyoacán México.
\end{abstract}

\section{-Mail Address}

Corresponding author e-mail address Adrian Gloria-Trujillo

Doctorado en Ciencias Agropecuarias, Division de Ciencias Biologicas y de

la Salud, Universidad Autónoma

Metropolitana - Xochimilco. Calzada

del Hueso 1100, 04960. Villa Quietud

Coyoacán, México.

Phone: +525546993537

Email: ingagt86@gmail.com

\section{- Keywords}

Acacia concinna; Broiler chick; Eimeria;

Peptasan ${ }^{\circledR}$; Salinomycin.

\section{ABSTRACT}

Coccidiosis negatively impacts health and productive performance in broilers. Anticoccidial resistance has prompted alternatives to prevent and control this disease. Therefore, the objective of this study was to evaluate a plant feed additive consisting of Acacia concinna containing saponins (Peptasan ${ }^{\circledR}$ ) and compare its effectiveness with salinomycin in terms of performance of broilers challenged with Eimeria. In the first experiment, 300 Ross chicks ( 1 day old) were randomly distributed into a negative (uninfected and untreated), and positive control group (infected and untreated), and three levels of dietary Peptasan ${ }^{\circledR}$ (500, 750 and $1000 \mathrm{ppm})$. In the second experiment, the same number of chicks were distributed in two control groups (negative and positive), two levels of Peptasan $^{\circledR}$ (500 and 750 ppm) and one level of salinomycin (550 ppm). In both experiments chicks were challenged at day 21 of age with 100,000 oocysts of Eimeria acervulina, 50,000 oocysts of Eimeria maxima and 50,000 oocysts of Eimeria tenella. Dietary Peptasan ${ }^{\circledR}$ improved productive performance, reduced mortality and the number of oocysts in feces, as well as increased yellow pigmentation of the skin of challenged chickens. The plant feed additive Peptasan ${ }^{\circledR}$ containing Acacia concinna can be effectively used for preventing coccidiosis in broilers.

\section{INTRODUCTION}

Avian coccidiosis is caused by protozoa of the genus Eimeria that infect the intestinal mucosa (Chapman, 2017) and cause nutrient malabsorption, inefficient feed utilization, impaired body weight gain and mortality (Lee et al., 2012). The control of avian coccidiosis has depended on the application of attenuated vaccines and medication with ionophores or synthetic chemicals (Djemai et al., 2016). lonophores increase transmembran ion fluxes and dissipation of gradients to exert its anticoccidial effects (Novilla, 2018), but do not eradicate completely the parasites (Chapman, 2017). Ionophores have been banned in several countries and their frequent use has increased the presence of resistant Eimeria strains (Djemai et al., 2016) which has generated the need to develop safe and inexpensive methods to control poultry coccidiosis (Mohiti-Asli \& Ghanaatparast-Rashti, 2015).

Herbal products are emerging as a strategy to combat coccidiosis (Muthamilselvan et al., 2016; Abbas et al., 2017a). They are characterized by having bioactive components such as phenolic acids, alkaloids, terpenes, tannins and flavonoids (Abbas et al., 2012a), with antioxidant properties and anticoccidial activity (Abbas et al., 2017b) comparable to that of synthetic drugs (Mohiti-Asli \& GhanaatparastRashti, 2015).

Peptasan ${ }^{\circledR}$ is a commercial poly-herbal product containing several phytochemical compounds (Kumar et al., 2007), and is composed of 
Sánchez-Hernández C,

Castañeda-Gómez del Campo JA,

Trejo-Castro L, Mendoza-Martínez GD,

Gloria-Trujillo A
Evaluation of a Feed Plant Additive for Coocidiosis Control in Broilers Herbals for Coccidiosis Control several plants including the legume Acacia concinna, which has high concentration of saponins (Jelassi et al., 2016), active compounds against coccidia that may be lethal to the parasites by inducing oxidative stress (Abbas et al., 2012b). Due to the presence of these active phytochemical compounds, Peptasan ${ }^{\circledR}$ could be an alternative in the control of avian coccidiosis. Therefore, the objective of the study was to evaluate the herbal additive Peptasan ${ }^{\circledR}$ and compare it with salinomycin in performance of broilers challenged with Eimeria acervulina, Eimeria maxima and Eimeria tenella.

\section{MATERIALS AND METHODS}

The study consisted of two experiments of 35 days each one, in which 300 day-old Ross ST308 chicks were used and challenged with E. acervulina, E. maxima and E. tenella. Both experiments were conducted in the experimental facilities of the Consultancy and Advisory Services in Animal Parasitology located in Jiutepec, Morelos, Mexico. In each experiment, the chicks were distributed in a completely randomized design in five groups, with six replicate cages with 10 birds per cage. The cages were provided with gutter-type feeders and tray type automatic drinkers.

Broilers were managed according to Mexican official standars (NOM-062-ZOO-1999; NOM-051ZOO-1995), and wildlife law of Morelos state (2017, Capitule 3, Articles 20 - 25; Capitule 5, Articles 32 35, and Capitule 8, Articles 44 - 52).

\section{Experiment 1}

At day 1, the chicks were distributed into five treatments: negative control group (uninfected and untreated birds), positive control group (birds infected with Eimeria and untreated) and three challenged groups, treated with three feed plant additive levels (500, 750 and 1000 ppm) of Peptasan ${ }^{\circledR}$ (Technofeed Mexico, Nuproxa Suiza, Indian Herbs Co.) in the feed (Crude protein 19.1\%; Metabolizable energy 3.027 Mcal kg-1; Ether extract 29.06\%). On day 21 of the experiment, each bird was challenged with a known number of sporulated oocysts (E. acervulina: 100,000 oocysts, E. maxima: 50,000 oocysts and E. tenella: 50,000 oocysts). The inoculum was orally inoculated mixed in $150 \mathrm{~g}$ of feed. The excreta of each treatment were collected daily from days 1 to 14 post- challenged, to determine the oocysts per gram of feces according to the methodology proposed by Johnson and Reid (1970). The amounts of feed offered and refusals were recorded daily to estimate the average daily feed intake. The individual body weight was measured every 7 days. Weight gain was calculated from the difference between initial and final weight in each period. The feed conversion ratio was calculated as the proportion of average feed intake: average daily gain. The mortality was recorded daily and expressed as the proportion of the number of dead per total number of chicks.

\section{Experiment 2}

In this experiment Peptasan ${ }^{\circledR}$ was compared with the commercial ionophore salinomycin. The chicks were distributed in a negative control group (uninfected and untreated birds), a positive control group (birds infected with Eimeria and untreated) and three challenged groups, two of which were treated with 500 and 750 ppm of Peptasan ${ }^{\circledR}$, and the third with salinomycin $(12 \%)$ at $550 \mathrm{ppm}$. On day 21 , the treatments to be infected received the challenge as described in the previous experiment. The feed intake, weight gain and feed conversion were measured according to the methodology described in experiment 1. At day 27 of the study, five birds per repetition (cage) selected at random were slaughtered by cervical dislocation. The anticoccidial efficacy was evaluated based on the injury index (Long et al., 1982). To calculate this index, the regions of the upper duodenum, middle jejunum and caecum were examined, because these are natural predilection sites for $E$. acervulina, E. maxima and $E$. tenella, respectively (Mohiti-Asli \& GhanaatparastRashti, 2015). The number of oocysts per gram of feces was evaluated as described in experiment 1 . The skin $b^{*}$ values were measured on the right apterial latero-pectoral area by using a reflectance colorimeter.

\section{Statistical analyses}

Data from both experiments were analyzed as a completely randomized design with JMP (Sall et al., 2012) and the normality of the variables was evaluated. The initial live weight was tested as a covariate and orthogonal contrasts were performed to test the linear and quadratic effect of the levels of the herbal product in the first experiment and those of the ionophore salinomycin in the second trial (Steel et al., 1997).

\section{RESULTS AND DISCUSSION}

\section{Productive performance}

In the experiment 1, Peptasan ${ }^{\circledR}$ at 750 ppm showed consumption levels similar to the negative control 
Sánchez-Hernández C,

Castañeda-Gómez del Campo JA,

Trejo-Castro L, Mendoza-Martínez GD,

Gloria-Trujillo A

\section{Evaluation of a Feed Plant Additive for Coocidiosis Control in Broilers Herbals for Coccidiosis Control}

group (Table 1). This same trend was observed in the final weight and daily weight gain $(p=0.23)$, as well as the feed conversion ( $p=0.18$ ) (Table 1). However, in this experiment the level of inclusion of Peptasan ${ }^{\circledR}$ in the diet seems to be important in terms of response of the bird because $750 \mathrm{ppm}$ showed better response compared to $1000 \mathrm{ppm}$ (Table 1). Kukhetpitakwong et al. (2006) referred to the toxicity of the extract of
A. concinna, the major component of Peptasan ${ }^{\circledR}$, that should be taken into consideration in animal use. $A$. concinna is rich in saponins, and their inclusion level can be beneficial or harmful depending on whether it is at low or high concentrations (Shi et al., 2013). Nevertheless, Peptasan ${ }^{\circledR}$ has been used in doses 10 times higher than those recommended without presenting toxicity in rats (Kumar et al., 2007).

Table 1 - Body weight, feed intake, body weight gains and feed conversion ratio of chicks unchallenged and challenged with Eimeria spp and fed with and without Peptasan ${ }^{\circledR}$

\begin{tabular}{|c|c|c|c|c|c|c|c|c|c|}
\hline \multirow[b]{2}{*}{ Variable* } & \multicolumn{5}{|c|}{ Treatments } & \multirow[b]{2}{*}{ SEM } & \multirow[b]{2}{*}{$p$-value } & \multirow[b]{2}{*}{ L } & \multirow[b]{2}{*}{ Q } \\
\hline & $\mathrm{N}^{\mathrm{a}}$ & $\mathrm{I}^{\mathrm{b}}$ & P500 & P750 & P1000 & & & & \\
\hline Final BW, g & 1546 & 1423 & 1493 & 1548 & 1432 & 23.05 & 0.24 & 0.77 & 0.12 \\
\hline Feed intake, $\mathrm{g} \mathrm{d}^{-1}$ & 69.12 & 69.88 & 68.4 & 69.06 & 68.77 & 0.12 & 0.001 & 0.24 & 0.07 \\
\hline$A D G, g$ & 42.9 & 39.4 & 41.5 & 42.8 & 39.5 & 0.66 & 0.24 & 0.77 & 0.12 \\
\hline Feed conversion & 1.62 & 1.77 & 1.65 & 1.62 & 1.75 & 0.03 & 0.18 & 0.62 & 0.19 \\
\hline
\end{tabular}

"Data are presented at day 35. ${ }^{\text {a }}$ Negative control group (uninfected and without additive in diet).

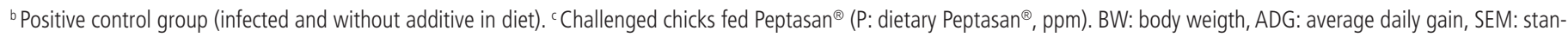
dard error of mean, P: probability value, L: linear effect Peptasan ${ }^{\circledR}$, Q: quadratic effect Peptasan ${ }^{\circledR}$.

In experiment 2, it was observed that at seven days of the experiment the positive and negative control groups recorded higher body weight $(p=0.0001)$ compared with chickens whose diets included Peptasan ${ }^{\circledR}$ and salinomycin (Table 2). On days 14 and 21 the body weight was similar among treatments and on days 28 and 35 challenged chickens that were fed with Peptasan ${ }^{\circledR}$ improved body weight $(p<0.01)$, feed intake $(p<0.001)$ and daily weight gain $(p<0.001)$ (Table 2).
Coccidiosis depresses growth by reducing feed intake and increases mortality due to a metabolic imbalance caused by the proliferation of the Eimeria and the destruction of the absorption surface in the intestine resulting in malabsorption of nutrients (Wajiha et al., 2018). In both experiments the inclusion of Peptasan ${ }^{\circledR}$ in the diet of chickens inoculated with coccidia allowed them to respond better to the challenge. This may be explained by the saponins in Acacia conccina, which include monoterpenoids

Table 2 - Body weight, feed intake, body weight gains and feed conversion ratio of chicks unchallenged and challenged with Eimeria spp and fed with and without Peptasan ${ }^{\circledR}$ and salinomycin.

\begin{tabular}{|c|c|c|c|c|c|c|c|c|c|c|}
\hline & \multicolumn{5}{|c|}{ Treatments } & \multirow[b]{2}{*}{ SEM } & \multirow[b]{2}{*}{$p$-value } & \multirow[b]{2}{*}{ L } & \multirow[b]{2}{*}{ Q } & \multirow[b]{2}{*}{$L^{*}$} \\
\hline & $\mathrm{N}^{\mathrm{a}}$ & $\mathrm{I}^{\mathrm{b}}$ & $\mathrm{P} 500^{c}$ & P750 & $S 550^{d}$ & & & & & \\
\hline \multicolumn{11}{|l|}{ Body weight, g } \\
\hline Day 1 & 45.83 & 45.33 & 45.83 & 44.83 & 45.33 & 0.189 & 0.44 & 1 & 0.34 & 0.41 \\
\hline Day 7 & 200.17 & 194.83 & 182.67 & 186.17 & 188.67 & 1.618 & 0.0009 & 0.0001 & 0.004 & 0.006 \\
\hline Day 14 & 496.17 & 495.67 & 494.83 & 486 & 479.33 & 4.213 & 0.67 & 0.92 & 0.75 & 0.23 \\
\hline Day 21 & 856.17 & 867.5 & 840.67 & 848 & 822.17 & 6.482 & 0.24 & 0.44 & 0.51 & 0.09 \\
\hline Day 28 & 1439 & 1195.33 & 1355.17 & 1325.83 & 1312.21 & 18.487 & 0.0001 & 0.04 & 0.42 & 0.003 \\
\hline Day 35 & 2043 & 1776.75 & 1978.52 & 1905.67 & 1907.5 & 20.298 & 0.0003 & 0.16 & 0.90 & 0.007 \\
\hline Feed intake, $\mathrm{g} \mathrm{d}^{-1}$ & 56.43 & 52.39 & 57.18 & 56.28 & 56.20 & 0.345 & 0.0001 & 0.13 & 0.06 & 0.64 \\
\hline$A D G, g^{-1}$ & 52.49 & 45.23 & 51.31 & 49.13 & 49.11 & 0.575 & 0.0004 & 0.37 & 0.63 & 0.01 \\
\hline Feed conversion & 1.092 & 1.167 & 1.117 & 1.145 & 1.143 & 0.01 & 0.29 & 0.48 & 0.93 & 0.14 \\
\hline
\end{tabular}

${ }^{a}$ Negative control group (uninfected and without additive in diet). ${ }^{b}$ Infected control group (infected and without additive in diet). c Challenged chicks fed Peptasan ${ }^{\circledR}$ (P: Dietary Peptasan ${ }^{\circledast}$, ppm). ${ }^{d}$ Challenged chicks fed salinomycinin diet (ppm). ADG: Average daliy gain, SEM: standard error of mean, P: probability value, L: linear effect Peptasan ${ }^{\circledR}$, Q: quadratic effect Peptasan ${ }^{\circledR}$. ${ }^{*}$ Linear effect of treatment with salinomycin.

like citronellal and sabinene (Lee-Rangel et al., 2017) and other compounds such as flavonoids, tannins, gums and mucilage with capacity to affect several microorganisms (Todkar et al., 2011) as well as immunomodulating properties (Kukhetpitakwong et al., 2006; Applegate, 2009) that improve overall health and productivity (Giannenas \& Kyriazakis, 2009; Pirali Kheirabadi et al., 2014; Wang et al., 2018). These properties may explain the better response of chickens treated with Peptasan ${ }^{\circledR}$ in body weight at seven days post challenge in comparison with chickens treated with salinomycin. 
Sánchez-Hernández C,

Castañeda-Gómez del Campo JA,

Trejo-Castro L, Mendoza-Martínez GD,

Gloria-Trujillo A Evaluation of a Feed Plant Additive for Coocidiosis
Control in Broilers Herbals for Coccidiosis Control

\section{Anticoccidial activity}

Table 3 shows that the inclusion of Peptasan ${ }^{\circledR}$ reduced the mortality in linear form $(p<0.05)$ and a correlation of $40 \% \quad(p=0.008)$ was detected between the number of oocysts in feces and the percentage of mortality. The excretion of oocysts in the negative control group was ruled out and there was a downward trend in reducing the oocysts count in feces with Peptasan ${ }^{\circledR}(p=0.06)$ with a high effectiveness against $E$. acervulina and E.tenella $(99 \%)$ and to a lesser extent against E. maxima (85\%) (Table 3).

Table 3 - Oocyst count and mortality of chicks unchallenged and challenged with Eimeria spp and fed with and without Peptasan $^{\circledR}$

\begin{tabular}{|c|c|c|c|c|c|c|c|c|c|}
\hline \multirow[b]{2}{*}{ Variable } & \multicolumn{5}{|c|}{ Treatments } & \multirow[b]{2}{*}{ SEM } & \multirow[b]{2}{*}{$p$-value } & \multirow[b]{2}{*}{$\mathrm{L}$} & \multirow[b]{2}{*}{$\mathrm{Q}$} \\
\hline & $\mathrm{N}^{\mathrm{a}}$ & $\mathrm{I}^{\mathrm{b}}$ & P500' & P750 & P1000 & & & & \\
\hline Mortality ${ }^{d}, \%$ & 0 & 10 & 1.11 & 7.5 & 1.25 & 1.04 & 0.002 & 0.03 & 0.06 \\
\hline Oocystse & 0 & 701667 & 61040 & 19875 & 9533 & 95793 & 0.07 & 0.90 & 0.90 \\
\hline E. acervulina & 0 & 368356 & 22500 & 6244 & 3344 & 50956 & 0.083 & 0.94 & 0.93 \\
\hline E. maxima & 0 & 23100 & 10567 & 6500 & 3325 & 4035 & 0.44 & 0.51 & 0.69 \\
\hline E. tenella & 0 & 196417 & 6967 & 4342 & 1108 & 38998 & 0.44 & 0.96 & 0.98 \\
\hline
\end{tabular}

${ }^{a}$ Negative control group (uninfected and without additive in diet). ${ }^{b}$ Positive control group (infected and without additive in diet ). ${ }^{\circ}$ Challenged chicks fed Peptasan ${ }^{\circledR}$ (P: Dietary Pepta$\operatorname{san}^{\circledR}$, ppm). ${ }^{d}$ Ratio of the number of dead per total number of chicks (\%). e Oocysts per gram of feces. SEM: standard error of mean, P: probability value, L: linear effect Peptasan ${ }^{\circledR}$, Q: quadratic effect Peptasan ${ }^{\circledR}$.

Mortality, in the second experiment, was reduced $(p=0.0001)$ to zero with Peptasan ${ }^{\circledR}$ and salinomycin compared to the infected control group where it was $25 \%$ (Table 4). Mortality was positively correlated $45 \%(p=0.012), 43 \%(p=0.019)$ and $56 \%(p=0.001)$ with the lesion index in the duodenum, jejunum and caecum, respectively.

Mortality depends on the level of infection (Christaki et al., 2004). The reduction in the excretion of oocysts in faeces is indicative of a lower degree of infection (Kucukyilmaz et al., 2012). The chickens with Peptasan ${ }^{\circledR}$ presented reduction of mortality, lower excretion of oocysts and a better productive performance, at seven days after inoculation when the maximum peak of excretion of oocysts occurs (Du \& Hu, 2004).

In contrast, the infected control group showed lesions in the duodenum and jejunum, with damage mainly in the caecum, with an index of lesions of 4 (Table
4), where E. tenella is associated with hemorrhages in the lumen of the caecum and bloody stools (Crespo \& Senties-Cue, 2015). Peptasan ${ }^{\circledR}$ reduced lesion score in duodenum, jejunum and cecum with the same efficacy as salinomycin. The lesion index in cecum was 0.83 for 500 ppm and 1.5 for 750 ppm, while in the treatment with salinomycin $(550 \mathrm{ppm})$ the index was $1.83(p=0.0001)$.

The polyphenolic components of Peptasan ${ }^{\circledR}$ interrupt the lipid structure of the cell membrane of parasites (Hassan et al., 2007), affecting the enzymatic and metabolic activity and resulting in cell death. This causes a toxic effect in the mature enterocytes in the intestinal mucosa causing cells infected with sporozoites to be released before the merozoite phase of the protozoa, responsible for the main clinical signs of coccidiosis (Mohiti-Asli \& Ghanaatparast-Rashti, 2015; Muthamilselvan et al., 2016). The end result

Table 4 - Anticoccidial activity in broiler chickens unchallenged and challenged with Eimeria spp and fed with and without Peptasan ${ }^{\circledR}$ and salinomycin.

\begin{tabular}{|c|c|c|c|c|c|c|c|c|c|c|}
\hline & \multicolumn{5}{|c|}{ Treatments } & \multirow[b]{2}{*}{ SEM } & \multirow[b]{2}{*}{$p$-value } & \multirow[b]{2}{*}{ L } & \multirow[b]{2}{*}{$\mathrm{Q}$} & \multirow[b]{2}{*}{$L^{f}$} \\
\hline & $\mathrm{N}^{\mathrm{a}}$ & $1^{b}$ & $\mathrm{P} 500^{\circ}$ & P750 & $\mathrm{S} 550^{\mathrm{d}}$ & & & & & \\
\hline Mortalitye, \% & 0.0 & 25.0 & 0.0 & 0.0 & 0.0 & 0.228 & 0.0001 & 1 & 1 & 1 \\
\hline \multicolumn{11}{|c|}{ Lesion index, day 27} \\
\hline Duodenum & 0.0 & 1.50 & 0.17 & 0.0 & 0.83 & 0.149 & 0.0006 & 0.63 & 0.58 & 0.02 \\
\hline Jejunum & 0.0 & 2.17 & 0.0 & 0.0 & 1.00 & 0.194 & 0.0001 & 0.99 & 0.99 & 0.01 \\
\hline Cecum & 0.0 & 4.00 & 0.83 & 1.50 & 1.83 & 0.319 & 0.0001 & 0.23 & 0.88 & 0.01 \\
\hline \multicolumn{11}{|l|}{ Pigmentation } \\
\hline$L^{*}$ & 64.59 & 64.77 & 64.39 & 63.83 & 64.83 & 0.177 & 0.39 & 0.73 & 0.69 & 0.67 \\
\hline$a^{*}$ & 3.92 & 3.96 & 4.29 & 4.06 & 4.30 & 0.142 & 0.87 & 0.42 & 0.44 & 0.41 \\
\hline$b^{*}$ & 14.44 & 11.05 & 12.14 & 9.35 & 11.61 & 0.342 & 0.0001 & 0.01 & 0.77 & 0.004 \\
\hline
\end{tabular}

${ }^{a}$ Negative control group (uninfected and without additive in diet). ${ }^{b}$ Infected control group (infected and without additive in diet). c Challenged chicks fed Peptasan ${ }^{\circledR}$ in diet (P: dietary Peptasan $^{\circledR}$, ppm). ${ }^{\circledR}$ Challenged chicks fed salinomycinin diet (ppm). e Ration of the number of dead per total number of chicks (\%). L*: Lightness, a*: Redness, $b^{*}$ : Yellowness, SEM: standard error of mean, P: probability value, L: linear effect, C: quadratic effect. ${ }^{f}$ Linear effect of treatment with salinomycin. 


\author{
Sánchez-Hernández C, \\ Castañeda-Gómez del Campo JA, \\ Trejo-Castro L, Mendoza-Martínez GD, \\ Gloria-Trujillo A
}

was a reduction in damage to the intestinal tissue and increased absorption of nutrients (Morris et al., 2007), which highlights the coccidicidal potential of the polyphenolic components in herbal products (Abbas et al., 2017a).

\section{Pigmentation of the skin}

The challenge with Eimeria strains reduced linearly $(p=0.019)$ the parameter $b^{*}$, related to the yellow pigmentation of the skin (Table 4). However, 500 ppm of Peptasan ${ }^{\circledR}$ improved the value of the parameter $b^{*}$ in the skin of the chickens challenged with Eimeria $(p=0.0001)$ (Table 4).

The increase in pigmentation of the skin of chickens treated with Peptasan ${ }^{\circledR}$ is due to the reduction in the rate of lesions in the intestinal tract. Frade et al. (2013) observed that in animals infected with coccidia the absorption of carotenoids was reduced by desquamation and shortening of the villi of the intestinal mucosa, and a continuous decrease in plasma carotenoids due to blood loss derived from hemorrhages in the cecal mucosa.

\section{CONCLUSIONS}

Peptasan ${ }^{\circledR}$ as a herbal additive improved animal performance, and represents a natural alternative in coccidiosis control in poultry. Peptasan ${ }^{\circledR}$ when supplemented at 500 ppm is effective against coccidiosis by reducing, oocysts excretion, intestinal lesions and mortality with the same efficacy as salinomycin (12\%) supplemented at $550 \mathrm{ppm}$.

\section{ACKNOWLEDGMENTS}

The authors acknowledge Technofeed Mexico, Indian Herbs and Nuproxa International in Switzerland for donating the herbal product. The authors also thank Ray Jones for his suggestions to improve the manuscript.

\section{REFERENCES}

Abbas ZR, Colwell DD, Gilleard J. Botanicals: an alternative approach forthe control of avian coccidiosis. World's Poultry Science Journal 2012a;68:203-215.

Abbas ZR, lqbal Z, Khan A, Shindu DUZ, Khan AJ, Khan NM, et al. Options for integrated strategies for the control of avian coccidiosis. International Journal of Agriculture \& Biology 2012b;14:1014-1020.

Abbas A, Iqbal Z, Abbas ZR, Khan KM, Khan AJ, Hussain K, et al. Immunomodulatory effects of Camellia sinensis against coccidiosis in chickens. Journal of Animal and Plant Sciences 2017a;27:415-421.
Abbas A, Iqbal Z, Abbas ZR, Kasib KM, Ali KJ, Din SZ, et al. In vivo anticoccidial effects of Beta vulgaris (sugar beet) in broiler chickens. Microbial Pathogenesis 2017b;111:139-144.

Applegate TJ. Influence of phytogenics on the immunity of livestock and poultry. In: Steiner T, editor. Phytogenics in animal nutrition. Nottingham: Nottingham University Press; 2009. p.39-59.

Chapman DH. Coccidiosis in egg laying poultry. In: Hester P, editor. Egg innovations and strategies for improvements. London: Academic Press; 2017. p.571-579.

Christaki E, Florou-Paneri P, Giannenas I, Papazahariadou M, Bot-soglou AN, Spais BA. Effect of a mixture of herbal extracts on broiler chickens infected with Eimeria tenella. Animal Research 2004;53:137-144.

Crespo R, Senties-Cue G. Postmortem survey of disease conditions in backyard poultry. Journal of Exotic Pet Medicine 2015;24:156-163.

Djemai S, Mekroud A, Jenkins CM. Evaluation of ionophore sensitivity of Eimeria acervulina and Eimeria maxima isolated from the Algerian to Jijel province poultry farms. Veterinary Parasitology 2016;224:77-81.

Du A, Hu S. Effects of herbal complex against Eimeria tenella infection in chickens. Journal of Veterinary Medicine 2004;51:194-197.

Frade NNJ، González LA, Hernández VX, Fuente MB, Quiroz PM, Ávila GE. Efecto de tres diferentes niveles de infección con Eimeria spp sobre el amarillamiento cutáneo y los niveles de carotenoides plasmáticos en pollos de engorda. In: Petrone GMV, editor. Memorias de la sexta reunión anual de AECACEM. Queretaro; 2013. p.72-76.

Giannenas I, Kyriazakis I. Phytobased products for the control of intestinal diseases in chickens in the post antibiotic era. In: Steiner T, editor. Phytogenics in animal nutrition. Nottingham: Nottingham University Press; 2009. p.61-85.

Hassan SM, Gutierrez O, Haq AU, Byrd JA, Bailey AC, Cartwright AL. Saponin-rich extracts from quillaja, yucca, soybean, and guar differ in antimicrobial and hemolytic activities. Poultry Science 2007;86:121.

Jelassi A, Ayeb-Zakhama EA, Nejma BA, Chaari A, Harzallah-Skhiri F, Jannet $\mathrm{BH}$. Phytochemical composition and allelopathic potential of three Tunisian Acacia species. Industrial Crops and Products 2016;83:339345 .

Johnson J, Reid VM. Anticoccidial drugs: lesión scoring techniques in battery and floor-pen experiments with chickens. Experimental Parasitology 1970;28:30-36.

Kucukyilmaz K, Bozkurt M, Selek N, Güven E, Eren H, Atasever A, et al. Effects of vaccination against coccidiosis, with and without a specific herbal essential oil blend, on performance, oocyst excretion and serum IBD titers of broilers reared on litter. Italian Journal of Animal Science 2012;11:1-8.

Kukhetpitakwong R, Hahnvajanawong C, Homchampa P, Leelavatcharamas V, Satra J, Khunkitti W. Immunological adjuvant activities of saponin extracts from the pods of Acacia concinna. International Immunopharmacology 2006;6:1729-1735.

Kumar A, Mandil R, Sharma A, Agrawala S. Sub-acute toxicity study of CocciBan. Phytomedica 2007:8:35-42.

Lee WK, Lillehoj SH, Jang IS, Pagés M, Bautista AD, Pope RC, et al. Effects of in ovo vaccination and anticoccidials on the distribution of Eimeria spp. in poultry litter and serum antibody titers against coccidia in broiler chickens raised on the used litters. Research in Veterinary Science 2012;93:177-182.

Lee-Rangel HA, Gazga JG, Mendoza GD, Mejia MA, Hernández PA, Flores $R R$, et al. Comparación de un coccidostato herbal y doramectina en el crecimiento de corderos y carga parasitaria en alimentación intensiva. Anales del 18th Congreso Bienal AMENA; 2017; Puerto Vallarta, Jalisco, México; 2017. 
Sánchez-Hernández C

Castañeda-Gómez del Campo JA,

Trejo-Castro L, Mendoza-Martínez GD,

Gloria-Trujillo A

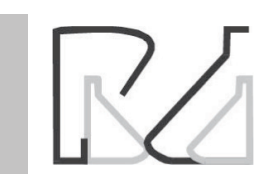

Evaluation of a Feed Plant Additive for Coocidiosis Control in Broilers Herbals for Coccidiosis Control
Long PVL, Malcom RW. A guide for diagnosis of coccidiosis in chickens. College of Agriculture Experimental Station Research Report 1982;404:1-17

Mohiti-Asli M, Ghanaatparast-Rashti M. Dietary oregano essential oil alleviates experimentally induced coccidiosis in broilers. Preventive Veterinary Medicine 2015;120:195-202

Morris GM, Woods WG, Richards GD, Gasser RB. Investigating a persistent coccidiosis problem on a commercial broiler ebreeder farm utilizing PCR-coupled capillary electrophoresis. Parasitology Research 2007; 101:583-589.

Muthamilselvan T, Tien-Fen K, Yueh-Chen W, Wen-Chin Y. Herbal remedies for coccidiosis control: a review of plants, compounds, and anticoccidial actions. Evidence-Based Complementary and Alternative Medicine 2016:2016:1-19

Novilla NM. Ionophores. In: Gupta CR, editor. Veterinary toxicology, $3^{\text {rd }}$ ed. London: Academic Press; 2018. chapter 78, p.1073-1092.

Pirali Kheirabadi K, Kaboutari-Katadj J, Bahadoran S, Teixeira da Silva JA, Dehghani-Samani A, Cheraghchi-Bashi M. Comparison of the anticoccidial effect of granulated extract of Artemisia sieberi with monensin in experimental coccidiosis in broiler chickens. Experimental Parasitology 2014;141:129-133.

Sall J, Lehman A, Stephens M, Creighton L. JMP® Start statistics: a guide to statistics and data analysis. $5^{\text {th }}$ ed. Cary: SAS Institute; 2012

Shi YH, Wang J, Guo R, Wang CZ, Yan XB, Xu B, et al. Effects of alfalfa saponin extract on growth performance and some antioxidant indices of weaned piglets. Livestock Science 2014;167:257-262.

Steel GD, Torrie JH, Dickey DA. Principles and procedures of statistics: a biometrical approach. $3^{\text {rd }}$ ed. New York; McGraw-Hill; 1997.

Todkar S, Todkar R, Kavathekar V, Kulkarni S, Kulkarni A. Secondary metabolite profiling of Acacia concinna. Biosciences Biotechnology Research Asia 2011;8:653-660.

Wajiha, Akhtar QN, Afridi R. Comparative analysis of egg adapted vaccines and salinomycin against coccidiosis in chicks. Microbial Pathogenesis 2018;123:454-460

Wang D, Zhou L, Li W, Zhou H, Hou G. Anticoccidial effects of areca nut (Areca catechu L.) extract on broiler chicks experimentally infected with Eimeria tenella. Experimental Parasitology 2018;184:16-21. 